\title{
Spatiotemporal Separation of Groundnut Rosette Disease Agents
}

\author{
R. A. Naidu, F. M. Kimmins, J. Holt, D. J. Robinson, C. M. Deom, and P. Subrahmanyam
}

First and sixth author: International Crops Research Institute for the Semi-Arid Tropics (ICRISAT), P.O. Box 1096, Lilongwe, Malawi; second and third authors: Pest Management Department, Natural Resources Institute, Chatham Maritime, Kent ME4 4TB, United Kingdom; fourth author: Virology Department, Scottish Crop Research Institute (SCRI), Invergowrie, Dundee DD2 5DA, United Kingdom; and fifth author: Department of Plant Pathology, University of Georgia, Athens 30602-7274.

Current address of R. A. Naidu: Department of Plant Pathology, University of Georgia, Athens 30602-7274.

Accepted for publication 22 June 1999.

\begin{abstract}
Naidu, R. A., Kimmins, F. M., Holt, J., Robinson, D. J., Deom, C. M., and Subrahmanyam, P. 1999. Spatiotemporal separation of groundnut rosette disease agents. Phytopathology 89:934-941.

Analysis by triple-antibody sandwich enzyme-linked immunosorbent assay of groundnut samples from fields in two seasons from different regions of Malawi showed the absence of groundnut rosette assistor virus (GRAV) from some plants showing groundnut rosette disease symptoms and the presence of GRAV in some symptomless plants. Viruliferous Aphis craccivora collected from fields transmitted either GRAV alone, groundnut rosette virus (GRV) with its satellite RNA (sat RNA), or all three agents together, in different proportions. More plants became infected

with all three agents when increasing numbers of potentially viruliferous aphids were used per plant, suggesting a dosage response. Electrical pentration graph studies of aphid stylet activities indicated successful transmission of GRV and its sat RNA during both the "stylet pathway phase" and salivation into sieve elements, whereas GRAV was transmitted only during the latter phase. Aphids transmitted all three agents together only during the salivation phase. Reverse-transcriptase polymerase chain reaction testing of viruliferous aphids and of inoculated plants revealed no correlation between the presence of all three agents in prospective aphid vectors and their simultaneous transmission to groundnut plants. These results show that separation of the groundnut rosette disease agents occurs over time and space.
\end{abstract}

Groundnut rosette disease is one of the major factors limiting production of groundnut (peanut, Arachis hypogaea) in sub-Saharan Africa (SSA). The disease is endemic to SSA and its off-shore island Madagascar (20) and is transmitted by the aphid Aphis craccivora Koch. (31,37). Among plant virus diseases, groundnut rosette disease is of special interest because of its complex etiology and its economic impact on the sustainability of groundnut, a subsistence crop in the small-holder agriculture of many SSA countries.

Groundnut rosette disease is caused by a complex of three agents (Table 1): groundnut rosette assistor virus (GRAV, family Luteoviridae) $(15,28)$, groundnut rosette virus (GRV, genus Umbravirus) $(19,33)$, and the satellite RNA (sat RNA) of GRV $(2,18)$. The disease occurs in SSA as two predominant symptom forms, "chlorotic rosette" and "green rosette" $(8,11,32)$, although variability in symptoms has been reported recently (21). Chlorotic rosette is apparently ubiquitous in groundnut in SSA, whereas green rosette has been reported only from West African countries and from Uganda, northern Malawi, and Angola.

The sat RNA is largely responsible for disease symptoms, and different symptom forms of the disease are due to variants of sat RNA $(17,18)$. Neither GRAV nor GRV cause any obvious symptoms alone or, at most, a transient mottle in groundnut; nevertheless, they both play crucial roles in the biology of groundnut rosette disease. It has been shown that GRV provides the replication function for the sat RNA, while GRAV functions as a helper virus in vector

Corresponding author: R. A. Naidu; E-mail address: naidu@arches.uga.edu

Mention of proprietary or brand names are necessary to report factually on available data. However, the mention of firm names or trade products does not imply that they are endorsed or recommended by United Kingdom Department for International Development, Peanut Collaborative Research Support Program, or the authors over other firms or similar products not mentioned.

Publication no. P-1999-0802-01R

(C) 1999 The American Phytopathological Society transmission $(15,16)$. GRV RNA and sat RNA are packaged together in the coat protein of GRAV to form virus particles that the aphid vector can transmit (27). The sat RNA plays a key role in the disease transmission process because its presence in the source plant is essential for encapsidation of GRV RNA (27) and, therefore, for the GRAV-dependent transmission of GRV (16). Hence, GRV and its sat RNA have always been found together in nature (23). Successful transmission of groundnut rosette disease complex by the aphid vector and, consequently, the survival of the disease agents in nature depend on the intricate relationship among GRAV, GRV, and sat RNA.

Because GRV RNA and sat RNA are packaged within the GRAV coat protein, the vector transmission characteristics of groundnut rosette disease complex are influenced by GRAV but not by either of the other two agents. Nonetheless, vector transmission characteristics of groundnut rosette disease seem to be different from the persistent type of transmission, characteristic of luteoviruses. Earlier studies $(6,14)$ have reported a long acquisition access period (AAP; about $4 \mathrm{~h}$ for chlorotic rosette and $8 \mathrm{~h}$ for green rosette) and latent period (LP; median of 26.4 and $38.4 \mathrm{~h}$ for chlorotic and green rosette, respectively), but a brief inoculation access period (IAP; less than $10 \mathrm{~min}$ for either chlorotic or green rosette) for aphid transmission of the disease. In these studies, successful transmission was assessed by the appearance of groundnut rosette disease symptoms in the inoculated plants; therefore, the results strictly refer to transmission of GRV and its sat RNA. Although it seems likely that the minimum AAP and LP for GRAV alone are similar to those of the complex, the minimum IAP for GRAV may exceed that for GRV and sat RNA because of the need for the luteovirus (GRAV) to be inoculated into the phloem tissue (9). Previous studies (23) have shown that some groundnut rosette-diseased plants did not contain GRAV and that GRAV was also found in some symptomless plants. The vector aphid failed to acquire and transmit GRV and sat RNA from groundnut plants exhibiting rosette disease symptoms but lacking GRAV. In this article, we show that a single vec- 
tor aphid, even though it acquires GRAV, GRV, and sat RNA, does not always transmit the three agents together into the inoculated plant, resulting in separation of groundnut rosette disease agents in time and space. The importance of this phenomenon in the epidemiology of groundnut rosette disease is discussed.

\section{MATERIALS AND METHODS}

Collection of plant samples. Groundnuts are grown in two seasons in northern Malawi (between December and April under rainfed conditions and from May to October using residual moisture in rice-based production systems), whereas, in the central and southern parts of Malawi, the crop is grown during the rainy summer season (October to April). Both chlorotic and green rosette are present in northern Malawi, whereas only chlorotic rosette occurs in other regions of Malawi. Samples were collected from the northern (Karonga area) and central (Lilongwe and Mchinji areas) regions of Malawi in both seasons during the 1996-1997 and 1997-1998 crop seasons. Leaf samples were collected at random in farmers' fields from individual plants showing typical rosette (either chlorotic or green) symptoms as well as from apparently symptomless plants, both adjacent to and distant from the infected plant. These samples were tested for groundnut rosette disease agents at either the International Crops Research Institute for the Semi-Arid Tropics (ICRISAT) facilities at Chitedze Agricultural Research Station, near Lilongwe, Malawi, or the Natural Resources Institute (NRI), Chatham Maritime, United Kingdom.

Vector transmission studies using field-collected aphids. Adult aphids (both alatae and apterae) were collected in farmers' fields in the Karonga and Lilongwe areas from colonies on either chlorotic or green rosette-affected groundnut plants. Triple-antibody sandwich enzyme-linked immunosorbent assay (TAS-ELISA) tests for the presence of GRAV were done on infected plants from which aphids were collected prior to utilizing the aphids in transmission studies. Individual aphids were transferred onto 10-dayold rosette-susceptible healthy groundnut seedlings (cv. Malimba) at one aphid per plant and covered with insect-proof perforated Crysp bags (Cryovac Europe, St. Neots, United Kingdom). After a 72-h IAP, aphids were killed by spraying plants with Actellic 50 emulsifiable concentration (a.i. $500 \mathrm{~g}$ of pirimiphos-methyl per liter). Plants were covered with plastic bags to prevent external infection and kept in a glasshouse fitted with a desert cooling system to maintain a daytime temperature of $30 \pm 5^{\circ} \mathrm{C}$. At 30 days after inoculation, groundnut plants were tested by TAS-ELISA for GRAV as described below and scored for rosette disease symptoms (either chlorotic or green). The development of rosette disease symptoms in groundnut was indicative of infection by both GRV and sat RNA $(18,23)$. Therefore, no attempt was made to test symptomless groundnut plants for infection by GRV without sat RNA, because separation of these two agents has not been recorded in aphid transmission experiments or in nature.

Vector transmission studies using aphids reared in the glasshouse. A colony of nonviruliferous A. craccivora, derived from a single aphid and routinely maintained on healthy groundnut plants (cv. Malimba) at the ICRISAT facilities at Chitedze Agricultural Research Station, was used for carrying out vector transmission studies. To ascertain the nonviruliferous status of the aphid culture, these plants were routinely monitored for groundnut rosette disease symptoms and tested by TAS-ELISA for the presence of GRAV. Groundnut plants showing symptoms of chlorotic and green rosette were collected from Chitedze and Karonga, respectively. The two symptom types were maintained separately on groundnut plants (cv. Malimba) by aphid transmission using glasshouse-reared nonviruliferous aphids.

Five nonviruliferous adult aphids from the glasshouse culture were released onto young groundnut plants showing either chlorotic or green rosette symptoms (tested positive for GRAV by TASELISA) for raising viruliferous aphid colonies. Viruliferous adults (alatae and apterae) from these colonies were transferred onto 10-dayold groundnut seedlings (cv. Malimba) at one aphid per plant and covered with insect-proof perforated Crysp bags. Subsequent transmission studies and testing of plants were done as described above.

Additional transmission studies in growth chambers were done at NRI to study the correlation between detection in vector aphids of groundnut rosette disease agents and their transmission. A nonviruliferous aphid culture (obtained from a culture maintained at ICRISAT, Chitedze Agricultural Research Station) and groundnut plants (cv. Malimba) infected with either chlorotic or green rosette disease were maintained under controlled conditions in environmental growth chambers $\left(25 \pm 2^{\circ} \mathrm{C}, 14\right.$-h day length, and $80 \%$ relative humidity $[\mathrm{RH}]$ ). Adult aphids (alatae and apterae) were collected from colonies raised on either chlorotic or green rosette-diseased plants (tested positive for GRAV by TAS-ELISA), and transmission studies were conducted as described above. After a 72-h IAP, individual aphids were collected and tested for GRAV and GRV by reverse-transcriptase polymerase chain reaction (RT-PCR) as described below. Plants were sprayed with Rapid (a.i. pirimicarb, $50 \% \mathrm{wt} / \mathrm{wt}$ ) to kill progeny aphids and kept in a separate growth room $\left(25 \pm 2{ }^{\circ} \mathrm{C}, 14\right.$-h day length, and $\left.80 \% \mathrm{RH}\right)$ for symptom development. At 1 month after inoculation, leaf samples from these plants were analyzed by TAS-ELISA and RT-PCR for the presence of GRAV and GRV, respectively.

Transmission studies involving multiple aphids. Transmission tests were conducted in which one, two, four, or eight viruliferous aphids were placed on each healthy 10-day-old groundnut seedling (cv. Malimba) as described above. At 1 month after inoculation, plants were scored for symptoms and tested for GRAV to determine the inoculation rates of GRV plus sat RNA, GRAV alone, and all three together. To examine whether infection by GRAV and by GRV plus sat RNA were statistically independent (whether infection with all three agents occurred as effectively when the agents were inoculated separately by different aphids as when all agents were inoculated by the same aphid), a simple probabilistic model was devised. If inoculation of GRV plus sat RNA or GRAV occur independently, the expected probabilities can be calculated as follows: let the probabilities of transmission by a single aphid of all three disease agents, GRAV only, GRV plus sat RNA only, and none, be $B_{1}, A_{1}, V_{1}$, and $O_{1}$, respectively, and the equivalent probabilities of transmission by $n$ aphids in combination be $B_{n}, A_{n}, V_{n}$, and $O_{n}$, respectively. The transmission probabilities for $n+1$ aphids are given by equation set 1: $A_{n+1}=A_{n} O_{1}+A_{1} O_{n}+A_{n} A_{1} ; V_{n+1}=V_{n} O_{1}+$ $V_{1} O_{n}+V_{n} V_{1} ; O_{n+1}=O_{n} O_{1}$; and $B_{n+1}=1-\left(A_{n+1}+V_{n+1}+O_{n+1}\right)$.

By iteration of equation set 1 , the expected probabilities associated with two, four, and eight aphids were obtained and the values

TABLE 1. Properties of groundnut rosette disease agents and methods for their detection ${ }^{\mathrm{a}}$

\begin{tabular}{|c|c|c|c|c|c|c|c|}
\hline \multirow[b]{2}{*}{ Agent $^{\mathrm{b}}$} & \multirow[b]{2}{*}{ Genus } & \multirow[b]{2}{*}{ Replication } & \multicolumn{2}{|c|}{ Transmission on groundnuts } & \multirow[b]{2}{*}{ Symptoms } & \multicolumn{2}{|c|}{ Detection $^{\mathrm{c}}$} \\
\hline & & & Mechanical & Aphid & & TAS-ELISA & RT-PCR \\
\hline GRAV & Luteovirus & Autonomous & No & Yes & Symptomless infection (transient mottle) & Yes & Yes \\
\hline GRV & Umbravirus & Autonomous & Yes & Yes, requires GRAV \& sat RNA & Symptomless infection (transient mottle) & No & Yes \\
\hline sat RNA & $\ldots$ & Requires GRV & Yes, requires GRV & Yes, requires GRAV \& GRV & Chlorotic, green, mosaic, etc. & No & Yes \\
\hline
\end{tabular}

a Adapted from Naidu et al. (22).

b GRAV = groundnut rosette assistor virus, GRV = groundnut rosette virus, and sat RNA = satellite RNA.

c TAS-ELISA = triple-antibody sandwich enzyme-linked immunosorbent assay, and RT-PCR = reverse-transcription polymerase chain reaction. 
of $B_{1}, A_{1}, V_{1}$, and $O_{1}$ estimated by minimizing the sums of squares between the observed numbers and those expected from equation set 1 .

Electrical penetration graph (EPG) studies. The EPG system developed by Tjallingii (36) was used to study the correlation between the aphid's stylet penetration activities and transmission of groundnut rosette disease agents. Aphid stylet penetration activities were recorded using signals from a direct current system, and the resulting EPG has been described as a sequence of distinctive patterns (24). These patterns have been correlated with activities including stylet pathway activities (pattern $\mathrm{C}$ ), membrane puncture by stylet tips (potential drops), salivation into phloem sieve elements (pattern E1), and phloem sap ingestion (pattern E2).

Adult apterous aphids were collected from a stock culture maintained on chlorotic rosette-infected groundnut plants (cv. Malimba) that showed a positive reaction for GRAV in TAS-ELISA. A 20- $\mu$ mdiameter gold wire (Goodfellow Metals, Cambridge, United Kingdom) was attached to the dorsum of each aphid with a water-based silver conductive paint (Leitselber type L2027; Demetron, Frankfurt, Germany). The opposite end of the wire was connected to one input of an amplifier (1 G $\Omega$ input impedance and a gain of $50 \times)(35,36)$. The other electrode was inserted into the soil in a pot containing a groundnut plant (cv. Malimba) on which the aphid was allowed to feed, thus completing the circuit. The experiments began as soon as the aphid had access to the plant and the EPG waveforms were recorded on a paper chart recorder (Graphtec WR7500 [AH3501], band width of 5 to $75 \mathrm{~Hz}$, chart speed of $10 \mathrm{~mm} \mathrm{~s}^{-1}$; Graphtec Ltd., Cheshire, United Kingdom) for a 2-h period or until a sustained potential drop followed by waveform E1 appeared in the EPG recordings. All experiments were carried out at an ambient temperature of $25 \pm 2^{\circ} \mathrm{C}$.

Testing of leaf samples by TAS-ELISA. Leaf samples were tested for the presence of GRAV by TAS-ELISA as described earlier (25). Immunogammaglobulin $\mathrm{G}$ ( $\mathrm{IgG}$ ) purified from polyclonal antibodies raised against purified preparations of GRAV was diluted to $1 \mu \mathrm{g} \mathrm{ml}^{-1}$ and used to coat the microtiter plates (Greiner $\mathrm{GmbH}$, Frickenhausen, Germany). Monoclonal antibody to potato leafroll virus (SCR6), which cross-reacts with the GRAV coat protein, was used as the secondary antibody. Anti-mouse IgG-alkaline phosphatase conjugate (Sigma Chemical Co., St. Louis) was used at 1:1,000 dilution as the detecting antibody. After adding the substrate ( $\rho$-nitrophenyl phosphate), plates were incubated for $4 \mathrm{~h}$ at room temperature and overnight at $5^{\circ} \mathrm{C}$ prior to obtaining absorbance readings at $A_{405}$ on a Titertek Multiscan Photometer (Lab-
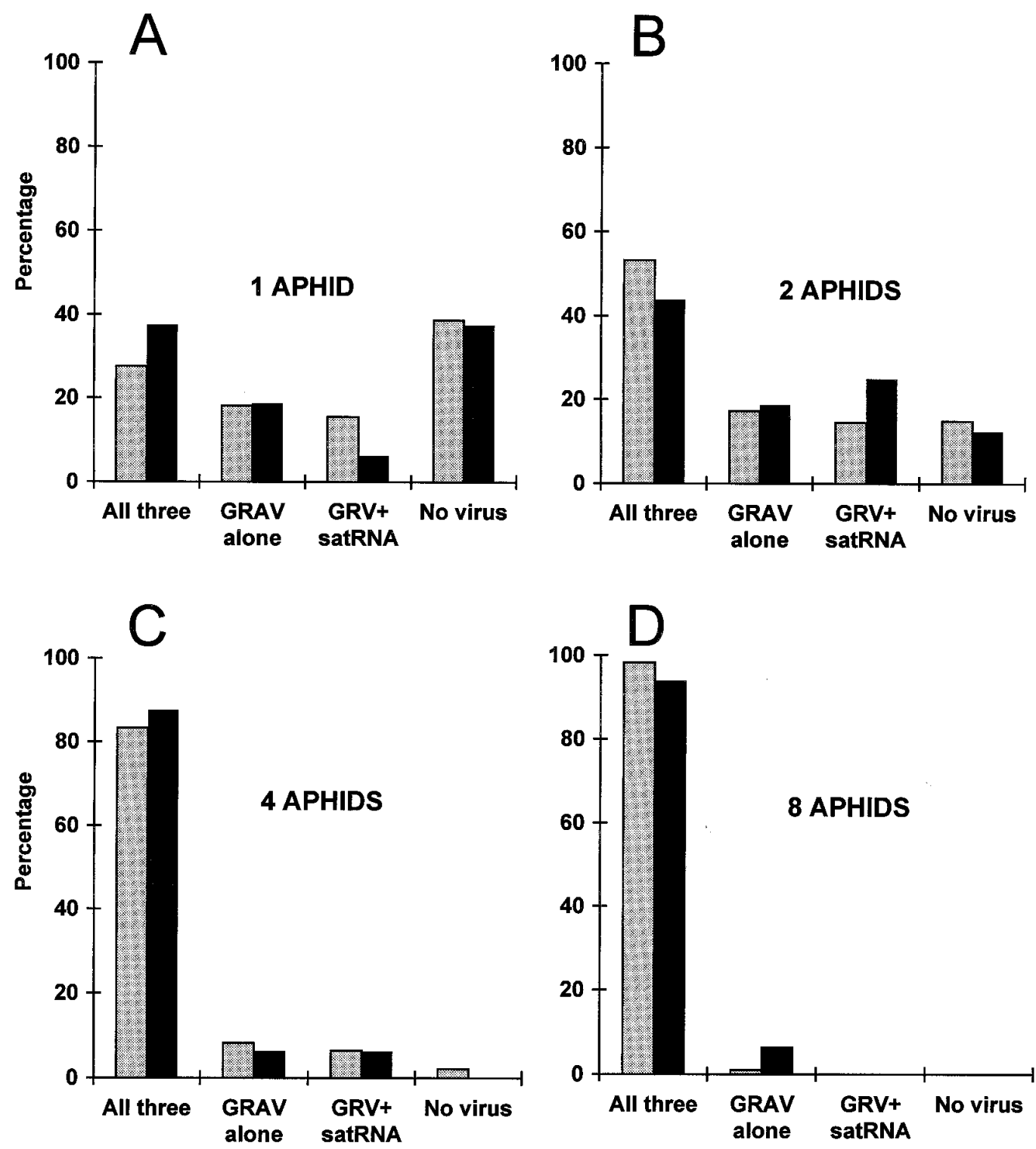

Fig. 1. Observed (shaded bar) and expected (solid bar) frequencies of transmission with one, two, four, and eight aphids. Expected values were derived on the assumption that infection with both components occurs at the same rate irrespective of whether the individual components are inoculated by the same or by different aphids. 
systems Oy, Helsinki, Finland). Each sample was assayed twice, and those with readings more than four times the value of healthy plant extracts were considered as positive for GRAV.

RT-PCR analysis of aphid and leaf samples. RT-PCR was done using the protocol described earlier (23) for the detection of GRAV and GRV in aphids and groundnut leaves. No tests were done for sat RNA in aphids because of the difficulty of detecting these molecules in individual aphids (23). However, aphids containing and transmitting GRV RNA must also contain sat RNA, since the latter is required for aphid transmission of GRV (16).

A RNeasy Plant Mini Kit (Qiagen Ltd., Crawley, United Kingdom) was used to extract total RNA from leaves and aphids. RTPCR was carried out using oligonucleotide primers. Primers GRAV1, 5'-ATGAATACGGTCGTGGTTAGG-3' (upstream primer), and GRAV-2, 5'-TTTGGGGTTTTGGACTTGGC-3' (downstream primer), corresponding to nucleotides 1 to 21 and 597 to 578, respectively, of the GRAV coat protein gene (28) were used to amplify a 597-base pair (bp) fragment diagnostic of GRAV. Primers GRV-1, 5'-GGAAGCCGGCGAAAGCTACC-3' (upstream primer), and GRV-2, 5'-GGCACCCAGTGAGGCTCGCC-3' (downstream primer), corresponding to nucleotides 2,584 to 2,603 and 3,447 to
3,428 , respectively, of GRV RNA (33) were used to amplify an 863-bp fragment diagnostic of GRV in both leaf tissue and aphids. PCR amplifications were done using the temperature regime described earlier (23): a denaturation phase at $94^{\circ} \mathrm{C}$ for 2 min followed by 35 cycles of amplification $\left(94^{\circ} \mathrm{C}\right.$ for $1 \mathrm{~min}, 55^{\circ} \mathrm{C}$ for $1 \mathrm{~min}$, $72^{\circ} \mathrm{C}$ for $2 \mathrm{~min}$ ), and a final extension at $72^{\circ} \mathrm{C}$ for $10 \mathrm{~min}$. A total of $10 \mu \mathrm{l}$ of RT-PCR products was analyzed by $1.2 \%$ agarose gel electrophoresis and visualized under UV light after staining with ethidium bromide.

\section{RESULTS}

Presence of GRAV in plants with or without rosette disease symptoms. Previous studies (23) have shown a correlation between rosette disease symptoms in groundnut plants and the presence of GRV and sat RNA and between RT-PCR and TAS-ELISA results for the presence of GRAV. Therefore, in this analysis, the presence of disease symptoms (either chlorotic or green rosette) was considered indicative of infection by GRV plus sat RNA. A positive reaction in TAS-ELISA was considered indicative of the presence of GRAV. Leaf samples collected from individual plants,
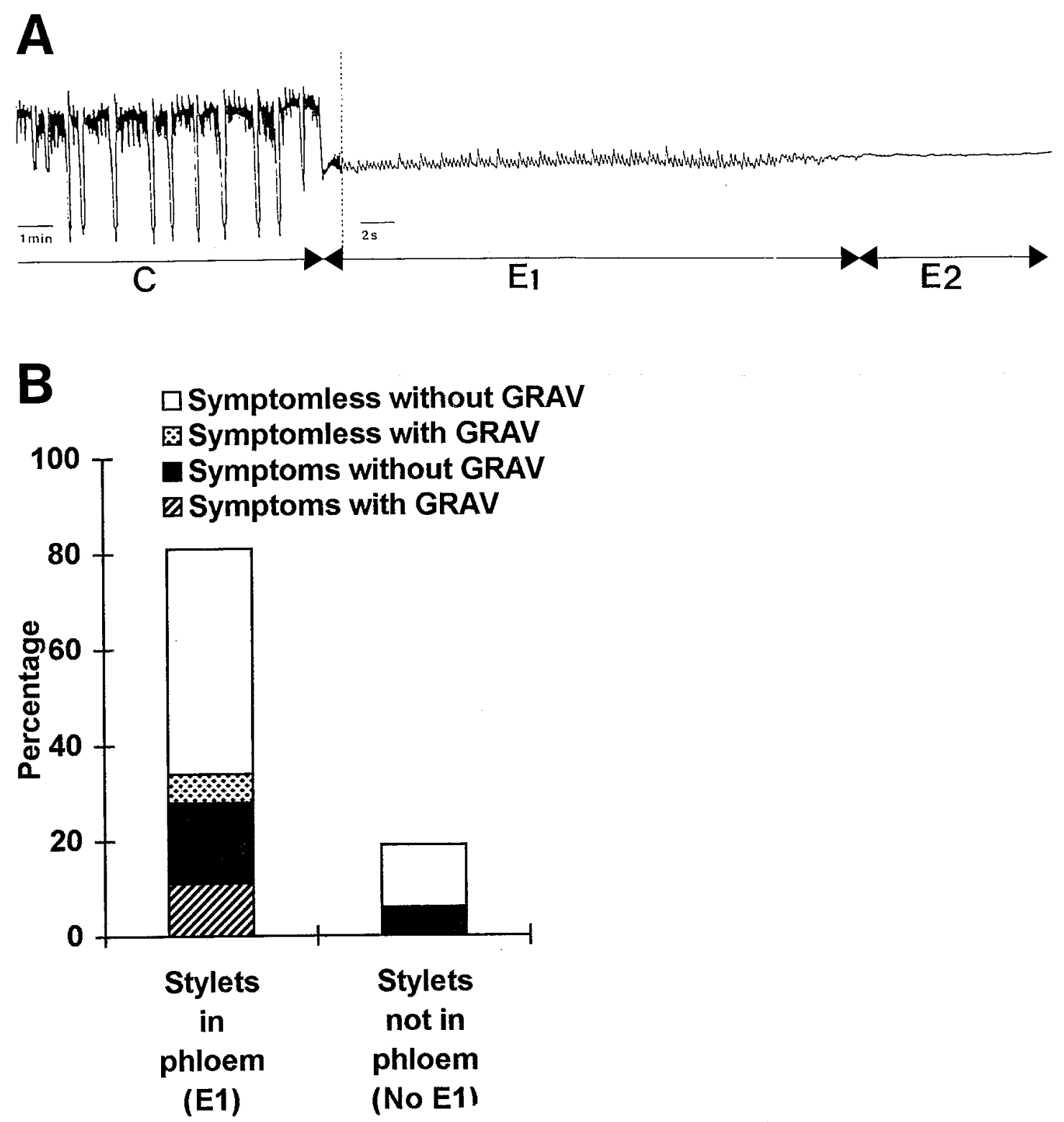

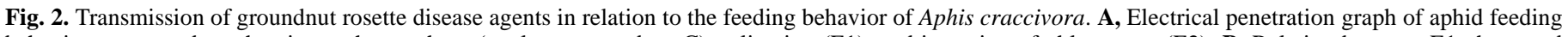

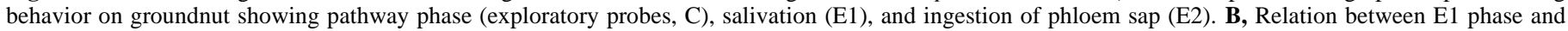
transmission of groundnut rosette disease agents. 
with or without groundnut rosette disease symptoms, were tested by TAS-ELISA for the presence of GRAV. Out of the 277 plants showing groundnut rosette disease symptoms, $221(80 \%)$ tested positive for GRAV and $56(20 \%)$ were negative. Of the 155 symptomless or apparently healthy-looking plants tested, only $16(10 \%)$ were positive for GRAV. This was observed irrespective of whether plants were exhibiting symptoms of chlorotic or green rosette. Similar results were obtained from samples collected in two seasons from the northern and central regions of Malawi.

Aphid transmission involving single aphids. The above results raise the question of whether viruliferous aphids transmit all three agents simultaneously. Previous results have shown that aphids did not transmit groundnut rosette disease when fed on plants showing groundnut rosette disease symptoms but lacking GRAV (13), because they failed to acquire GRV and sat RNA from such plants (23). Therefore, individual adult aphids (alatae and apterae) that were collected in farmers' fields from plants that showed symptoms of groundnut rosette disease and tested positive for GRAV were utilized in transmission studies. Since one aphid was placed per healthy seedling and each could potentially transmit all three agents during a 72-h IAP, transmission results reflect the ability of each individual viruliferous aphid to transmit the three agents. Out of the 326 viruliferous aphids tested from northern and central Malawi, $191(58 \%)$ transmitted the three disease agents together; infected plants showed groundnut rosette disease symptoms and tested positive for GRAV. However, 35 plants showed groundnut rosette disease symptoms but tested negative for GRAV and another 25 plants were symptomless but positive for GRAV, indicating, respectively, that $11 \%$ of aphids transmitted only GRV and sat RNA, whereas $8 \%$ transmitted only GRAV. A total of 75 plants were symptomless and tested negative for GRAV, suggesting that $23 \%$ of the aphids did not transmit any of the groundnut rosette disease agents. These results show that single viruliferous aphids do not always transmit the three agents together and that a certain proportion of them transmit either GRAV alone or GRV plus sat RNA. Although the values in each category varied among viruliferous aphids collected at different times within a region or from different regions, the trend was found to be consistent in all experiments with either chlorotic or green rosette disease.

Experiments carried out with aphids from colonies developed on plants having groundnut rosette disease (either chlorotic or green) and maintained in a glasshouse at ICRISAT or in the growth chambers at NRI gave results (data not shown) similar to those with aphids collected from the field.

Transmission studies involving multiple aphids. Because a single viruliferous aphid may or may not always transmit all three agents of the disease together, experiments were done with one, two, four, or eight aphids per plant to study the effect of increased number of viruliferous aphids on transmission of the three agents into each inoculated plant. A total of 20 individual plants was used in two separate experiments for each treatment (Fig. 1A to D). Only in about $30 \%$ of plants were all three agents transmitted from a single aphid. The number of plants having all three agents increased with two and four aphids per plant, reaching nearly $100 \%$ with inoculations involving eight viruliferous aphids per plant (Fig. 1B to D). Conversely, the percentage of plants having either GRAV alone or GRV plus sat RNA alone decreased as the number of viruliferous aphids per plant increased. These results were in good agreement with expected frequencies derived from a simple probabilistic model (Fig. 1A to D), and numbers of each of the four transmission possibilities do not differ significantly $\left(\chi^{2}=0.202\right.$, $\left.\mathrm{df}=3, P>0.95\right)$.

EPG studies. A total of $28(80 \%)$ of the 35 aphids tested produced a sustained potential drop ( $>15 \mathrm{~min}$ ) followed by patterns E1 and then E2 within the 2-h recording period (Fig. 2A). This indicated that the aphids' stylets had punctured the phloem tissues and initiated phloem feeding activities, first by salivating into the sieve elements (pattern E1) and then by ingesting phloem sap (pattern E2). The mean time taken to reach the phloem from the start of the experiment was $54.5 \mathrm{~min}$ (standard deviation [SD] $\pm 28.6 \mathrm{~min}$ ), and the mean time from the start of the phloem-locating probe was $21 \mathrm{~min}$ ( $\mathrm{SD} \pm 17 \mathrm{~min}$ ). The remaining seven aphids (20\%) did not produce a sustained potential drop during the 2-h recording period and, therefore, did not initiate phloem penetration activities.

Out of the 28 aphids that produced the E1 pattern, 11 (39\%) transmitted one or more of the causal agents of groundnut rosette disease. Of the 11 transmitters, only four $(36 \%)$ transmitted the three agents of rosette disease together, one $(9 \%)$ transmitted only GRAV, and six $(55 \%)$ transmitted only GRV and sat RNA (Fig. 2B). Of the seven aphids that did not produce the E1 pattern, only two (29\%) transmitted GRV and sat RNA (Fig. 2B). These results suggest that GRAV was only transmitted by aphids that produced the E1 pattern and that GRAV must be inoculated into the phloem sieve

A

GRAV

B

GRV
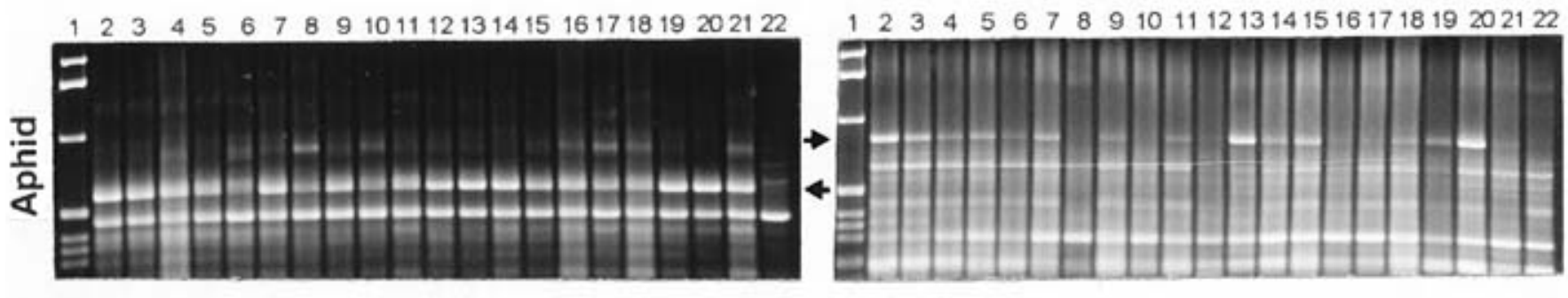

C

D
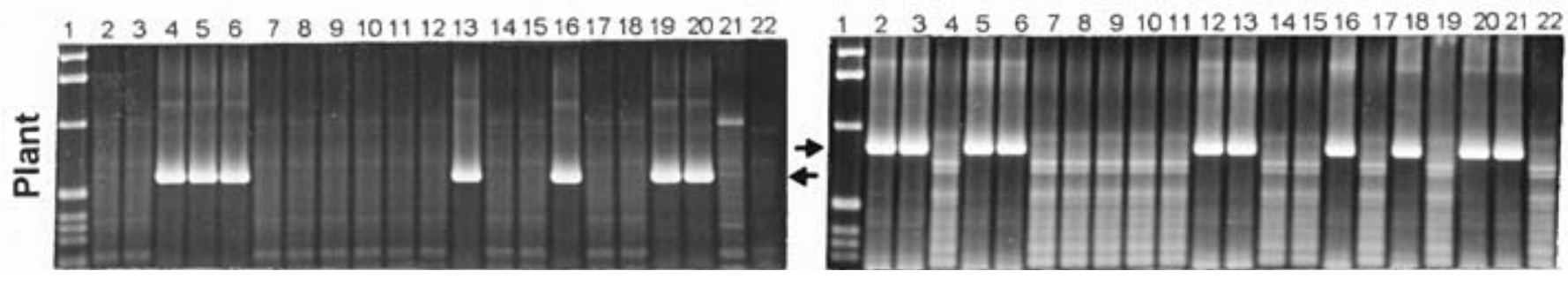

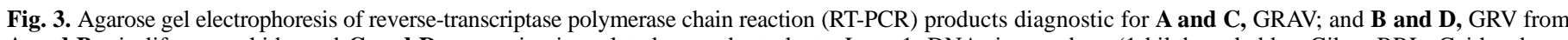

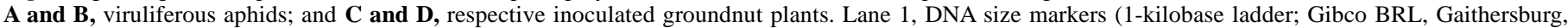

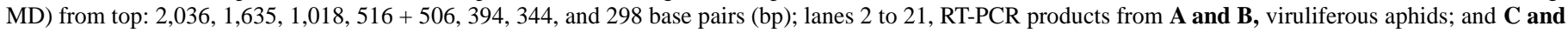

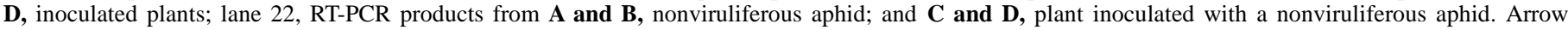
directed toward the left indicates position of a band diagnostic for GRAV (597 bp) and arrow toward the right indicates that diagnostic for GRV ( 863 bp). 
elements for successful transmission. Inoculation of GRV and sat RNA in the absence of the E1 pattern suggests that they can be transmitted by the vector into groundnut tissues other than the phloem sieve elements (into mesophyll and epidermis).

Correlation between the presence of rosette disease agents in aphids and their transmission. The above results raise the question of whether the viruliferous aphids that transmitted only GRAV lacked GRV and sat RNA and whether the aphids that transmitted GRV and sat RNA lacked GRAV. Therefore, experiments were done to study the correlation between the presence of rosette disease agents in aphids and their transmission to groundnut plants. Results from two of the four independent experiments, each consisting of 10 viruliferous aphids, are shown in Figure 3. The 550-bp fragment diagnostic for GRAV (Fig. 3A, lanes 2 to 21) (23) and the 860-bp fragment diagnostic for GRV (Fig. 3B, lanes 2 to 21) (23) were detected in viruliferous aphids but not in nonviruliferous aphids (Fig. 3A and B, lane 22). As described previously (23), a fragment of about $450 \mathrm{bp}$ was amplified with the GRAV primers from both viruliferous and nonviruliferous aphids, as were various products smaller than $860 \mathrm{bp}$ with the GRV primers. The intensity of the 860-bp GRV fragment (Fig. 3B) varied among individual aphid samples; it was readily detected in many of them and faint in others, perhaps due to varying concentrations of GRV in these aphids because they were tested after a 72-h IAP. Although the 860 -bp fragment is barely seen in lanes 8,10 , and 12 , it was visible in the gel under UV illumination.

RT-PCR analysis of corresponding plants, on the other hand, revealed the presence of GRAV (Fig. 3C, lanes 2 to 21) and GRV (Fig. 3D, lanes 2 to 21), either alone or together, in 12 out of 20 plants. GRV was detected only in plants showing symptoms of groundnut rosette disease (either chlorotic or green), suggesting that sat RNA was transmitted together with GRV. Of the 12 infected plants, five (Fig. 3C and D, lanes 5, 6, 13, 16, and 20) exhibited groundnut rosette disease symptoms (indicative of sat RNA) and had both GRAV and GRV, another five exhibited symptoms and had only GRV (Fig. 3C and D, lanes 2, 3, 12, 18, and 21), and the other two plants (Fig. 3C and D, lanes 4 and 19) did not show symptoms and contained only GRAV. When the number of aphids that transmitted either GRAV or GRV plus sat RNA were compared, a total of $60 \%$ of the viruliferous aphids transmitted rosette disease agents. Of these, $41.7 \%$ transmitted all three agents together, $41.7 \%$ transmitted only GRV plus sat RNA, and $16.7 \%$ transmitted GRAV only. These results show that, even though aphids acquire all three agents simultaneously, there is no correlation between the presence of these agents in the vector and the ability of aphids to transmit the disease.

\section{DISCUSSION}

Separate infections with GRAV or with GRV plus sat RNA following aphid transmissions from plants infected with all three agents have previously been observed in laboratory tests (16). Our results show that separation of GRV and sat RNA from GRAV also occurs in nature and, as a result, expression of groundnut rosette disease symptoms in groundnut plants does not necessarily indicate the presence of GRAV. Although the number of plants infected with either GRV plus sat RNA, GRAV alone, or all three agents together vary, this separation has been consistently observed in different seasons and regions of Malawi. We believe that this is not an isolated phenomenon and suspect that it happens in all groundnut-growing countries of SSA wherever this disease occurs. It has been reported that groundnut plants showing symptoms of rosette disease were more attractive to aphids, aphid populations developed faster, and higher numbers of winged adults were produced on plants showing groundnut rosette disease than on healthy plants (26; F. M. Kimmins, unpublished data). However, only diseased plants containing GRAV serve as sources of inoculum for field spread of the disease. Epidemiologically, therefore, diseased plants lacking GRAV are "dead ends" for the spread of the disease, even though such plants contribute to yield loss. Similarly, symptomless plants containing only GRAV may play a negligible role in the aphid-mediated spread of the disease. This separation could have a negative effect on the survival and perpetuation of GRV and sat RNA in groundnut; nonetheless, GRV and sat RNA seem not to have any influence on this process, because they are packaged in GRAV coat protein. Whether this separation happens only in groundnut, which became a host for rosette disease after its introduction into Africa sometime during the sixteenth century, or also in indigenous reservoir host plants that are yet to be identified (20) remains to be determined.

In another example of a helper-dependent virus complex, rice tungro disease, transmission by leafhoppers of the bacilliform virus is dependent upon a helper component encoded by the spherical virus (12). The presence of the bacilliform virus on its own in rice plants, however, represents less of a dead end than is the case for GRV and sat RNA in groundnut. Leafhopper vectors carrying the spherical virus can acquire the bacilliform virus from a subsequent host, without that host plant being infected with the spherical virus $(4,5)$. Rosette disease, on the other hand, represents a different system in that diseased plants containing only GRV plus sat RNA do not produce virus particles that the aphid vector can acquire. However, such a plant may have the potential to contribute to further disease spread if an aphid first inoculates GRAV into this plant so that GRAV RNA replicates and its coat protein becomes available to form particles containing GRV and sat RNA. Such a plant can serve as a potential source of the disease for transmission by another vector aphid. Since infected groundnut plants grow older during the period required for GRAV replication and aphids are less likely to prefer mature plants for feeding and virus acquisition (7), this is unlikely to happen in nature.

No correlation was observed between the presence of groundnut rosette disease agents in aphids and their ability to transmit them simultaneously to groundnut plants (Fig. 3). It is unlikely that the groundnut rosette disease agents detected by RT-PCR were present in the aphid's gut because, at the end of the 72-h IAP, it would be expected that the virus particles ingested during the acquisition period would have passed into the hemocoel, with some passing into the accessory salivary gland, or would have been eliminated in the voided honeydew (9). Lack of a correlation between the presence of virus in the aphid vector and transmission was also observed with other persistently transmitted viruses like beet western yellows virus and beet mild yellowing virus $(1,30)$. However, transmission of groundnut rosette disease seems to be more complex than these examples in that some of the aphids transmitted only GRAV or GRV (and sat RNA, because GRV-containing plants showed symptoms), even though they acquired all three disease agents.

The separation of the infective agents could result from the aphids acquiring only one kind of particle from the source plant. This possibility can be discounted because all viruliferous aphids tested by RT-PCR contained both GRAV and GRV (Fig. 3A and B). Alternatively, the inoculation feeding behavior of the viruliferous vector could be critical. This hypothesis is supported by the EPG studies, in which viruliferous aphids that probed groundnut leaves without reaching the phloem transmitted only GRV and sat RNA (Fig. 2B). Even though a sufficient number of particles containing GRAV RNA and those with GRV RNA plus sat RNA may be deposited into mesophyll cells during the exploratory probes, only GRV RNA and sat RNA will replicate and spread because GRAV, being a luteovirus, can replicate only in the phloem. As a result, such plants develop disease symptoms without infection by GRAV. On the other hand, inoculation of GRAV, with or with out GRV plus sat RNA, occurred only during the E1 phase, similar to other circulative viruses like barley yellow dwarf virus (24). What is interesting, however, is that among the viruliferous aphids that salivated into the phloem (indicated by E1 patterns) only some transmitted 
GRAV (either alone or together with GRV plus sat RNA) and some transmitted only GRV plus sat RNA (Fig. 2B). Although it is difficult to explain precisely how this happens, it is plausible that the ratio of particles containing GRV RNA plus sat RNA to those with GRAV RNA in an aphid and the number of salivations into phloem sieve elements dictate whether a single aphid inoculates a sufficient dose of each of the groundnut rosette disease agents to initiate infection. It is likely, therefore, that transmission of all three agents together would be enhanced by extending the IAP or increasing the number of aphids per plant. Support for this dosage-response relationship is discernible from data in Figure 1, in which infection with all three agents increased as the number of viruliferous aphids feeding per plant increased. Higher rates of infection and disease severity due to increased populations of viruliferous aphids $(3,29)$ or to higher virus titers in individual vector aphid (10) have been observed with other circulative viruses such as barley yellow dwarf virus. The data in Figure 1 suggests that infection with GRAV and GRV plus sat RNA occurs just as effectively when the three agents are inoculated separately by different aphids as when all of them are inoculated by the same aphid. The results are also consistent with the idea that inoculation is a purely probabilistic process, such that a relatively small probability of infection associated with a single feeding vector increases with multiple vectors due simply to an increased chance of infection rather than due to any enhanced infection risk due to a cumulative increase in the amount of inoculated virus.

Groundnut rosette disease is regarded as a polycyclic disease because it spreads from primary sources of inoculum whose number increases during the growing season as progressively increasing numbers of plants become sources (34). Thus, the number of groundnut plants in the field with primary infections containing all three disease agents, the conditions that lead to development of vector progeny on these primarily infected plants, the density and transmission efficiency of vector populations in a given field, and the number and frequency of inoculation events all influence whether all three agents are inoculated into a plant. Further studies are in progress to understand these parameters and their contribution toward the development of groundnut rosette disease epidemics.

\section{ACKNOWLEDGMENTS}

This paper is an output from research partially funded by the Department for International Development (DFID) of the United Kingdom (project no. R6811; Crop Protection Programme) for the benefit of developing countries and the Peanut Collaborative Research Support Program (Peanut CRSP) of the United States Agency for International Development (grant LAG-G-00-96-90013-00). The views expressed are not necessarily those of DFID. SCRI is grant-aided by the Scottish Office Agriculture, Environment and Fisheries Department. Submitted as Journal Article no. JA 2306 by the ICRISAT.

\section{LITERATURE CITED}

1. Barker, I., and Torrance, L. 1990. The relationship between barley yellow dwarf virus content in aphids and their ability to transmit. Pages 166-168 in: World Perspectives on Barley Yellow Dwarf. P. Burnett, ed. International Maize and Wheat Improvement Center (CIMMYT), Mexico D.F., Mexico.

2. Blok, V. C., Ziegler, A., Robinson, D. J., and Murant, A. F. 1994. Sequences of 10 variants of the satellite-like RNA-3 of groundnut rosette virus. Virology 202:25-32.

3. Burnett, P. A., and Gill, C. C. 1976. The response of cereals to increased dosage with barley yellow dwarf virus. Phytopathology 66:646-651.

4. Chowdhury, A. K., Teng, P. S., and Hibino, H. 1990. Retention of tungro-associated viruses by leafhoppers and its relation to rice cultivars. Int. Rice Res. Newsl. 15:31.

5. Chowdhury, A. K., Teng, P. S., and Hibino, H. 1990. Production of helper component in rice tungro (RTSV)-infected plants. Int. Rice Res. Newsl. 15:14.

6. Dubern, J. 1980. Mechanical and aphid transmission of an Ivory Coast strain of groundnut rosette virus. Phytopathol. Z. 99:318-326.
7. Farrell, J. A. K. 1976. Effects of groundnut crop density on the population dynamics of Aphis craccivora Koch (Hemiptera, Aphididae) in Malawi. Bull. Entomol. Res. 66:317-329.

8. Gibbons, R. W. 1977. Groundnut rosette virus. Pages 19-21 in: Diseases of Tropical Crops. J. Kranz, J. Schutter, and W. Koch, eds. Verlag Paul Parey, Berlin.

9. Gildow, F. E. 1987. Virus-membrane interactions involved in the circulative transmission of luteoviruses by aphids. Pages 93-120 in: Current Topics in Vector Research, Vol. 4. Springer-Verlag, New York.

10. Guo, J.-Q., and Lapierre, H. 1997. Clonal variations and virus regulation by aphids in transmission of a French PAV-type isolate of barley yellow dwarf virus. Plant Dis. 81:570-575.

11. Hayes, T. R. 1932. Groundnut rosette disease in the Gambia. Trop. Agric. (Trinidad) 9:211-217.

12. Hibino, H., and Cabunagan, R. C. 1986. Rice tungro-associated viruses and their relations to host plants and vector leafhoppers. Int. Symp. Virus Dis. Rice and Leguminous Crops Trop. Trop. Agric. Res. Ser. 19:173-182.

13. Hull, R., and Adams, A. N. 1968. Groundnut rosette and its assistor virus. Ann. Appl. Biol. 62:139-145.

14. Misari, S. M., Abraham, J. M., Demski, J. W., Ansa, O. A., Kuhn, C. W., Casper, R., and Breyel, E. 1988. Aphid transmission of the viruses causing chlorotic rosette and green rosette diseases of peanut in Nigeria. Plant Dis. 72:250-253.

15. Murant, A. F. 1989. Groundnut rosette assistor virus. AAB Descrip. Plant Viruses No. 345.

16. Murant, A. F. 1990. Dependence of groundnut rosette virus on its satellite RNA as well as on groundnut rosette assistor luteovirus for transmission by Aphis craccivora. J. Gen. Virol. 71:2163-2166.

17. Murant, A. F., and Kumar, I. K. 1990. Different variants of the satellite RNA of groundnut rosette virus are responsible for the chlorotic and green forms of groundnut rosette disease. Ann. Appl. Biol. 117:85-92.

18. Murant, A. F., Rajeshwari, R., Robinson, D. J., and Raschke, J. H. 1988. A satellite RNA of groundnut rosette virus that is largely responsible for symptoms of groundnut rosette disease. J. Gen. Virol. 69:1479-1486.

19. Murant, A. F., Robinson, D. J., and Gibbs, M. J. 1995. Genus Umbravirus. Pages 388-391 in: Virus Taxonomy-Classification and Nomenclature of Viruses. Sixth Rep. Int. Comm. Taxon. Viruses. F. A. Murphy, C. M. Fauquet, D. H. L. Bishop, S. A. Ghabrial, A. W. Jarvis, G. P. Martelli, M. A. Mayo, and M. D. Summers, eds. Springer-Verlag, Vienna.

20. Naidu, R. A., Bottenberg, H., Subrahmanyam, P., Kimmins, F. M., Robinson, D. J., and Thresh, J. M. 1998. Epidemiology of groundnut rosette virus disease: Current status and future research needs. Ann. Appl. Biol. 132:525-548.

21. Naidu, R. A., Kimmins, F., Delfosse, P., Alegbejo, M. D., and Waliyar, F. 1997. Groundnut rosette and peanut clump diseases in Western Africa. Pages 49-51 in: Groundnut Virus Diseases in Africa: Summary and Recommendations of the Sixth Meeting of the International Working Group, Agricultural Research Council, Plant Protection Research Institute, Pretoria, South Africa. D. V. R. Reddy, P. Delfosse, J. M. Lenne', and P. Subrahmanyam, eds. Int. Crops Res. Inst. Semi-Arid Trop. Andhra Pradesh, India; and Belg. Admin. Dev. Coop., Brussels, Belgium.

22. Naidu, R. A., Kimmins, F. M., Deom, C. M., Subrahmanyam, P., Chiyembekeza, A. J., and van der Merwe, P. J. A. 1999. Groundnut rosette: A virus disease affecting groundnut production in sub-Saharan Africa. Plant Dis. 83:700-709.

23. Naidu, R. A., Robinson, D. J., and Kimmins, F. M. 1998. Detection of each of the causal agents of groundnut rosette disease in plants and vector aphids by RT-PCR. J. Virol. Methods 76:9-18.

24. Prado, E., and Tjallingii, W. F. 1994. Aphid activities during sieve element punctures. Entomol. Exp. Appl. 72:157-165.

25. Rajeshwari, R., Murant, A. F., and Massalski, P. R. 1987. Use of monoclonal antibody to potato leaf roll virus for detecting groundnut rosette assistor virus by ELISA. Ann. Appl. Biol. 111:353-358.

26. Rèal, P. 1955. Le cycle annuel du puceron de l'arachide (Arachis leguminosae Theob.) en Afrique noire francaise et son déterminisme. Rev. Pathol. Veg. 34:3-122.

27. Robinson, D. J., Ryabov, E. V., Raj, S. K., Roberts, I. M., and Taliansky, M. E. 1999. Satellite RNA is essential for encapsidation of groundnut rosette umbravirus RNA by groundnut rosette assistor luteovirus coat protein. Virology 254:105-114.

28. Scott, K. P., Farmer, M.-J., Robinson, D. J., Torrance, L., and Murant, A. F. 1996. Comparison of the coat protein of groundnut rosette assistor virus with those of other luteoviruses. Ann. Appl. Biol. 128:77-83.

29. Smith, H. C. 1967. The effect of aphid numbers and stage of plant growth in determining tolerance to barley yellow dwarf virus in cereals. N.Z. J. Agric. Res. 10:445-466.

30. Stevens, M., Smith, H. G., and Hallsworth, P. B. 1995. Detection of the luteoviruses, beet mild yellowing virus and beet western yellows virus, in aphids caught in sugar-beet and oilseed rape crops, 1990-1993. Ann. 
Appl. Biol. 127:309-320.

31. Storey, H. H., and Bottomley, B. A. 1928. The rosette disease of peanuts (Arachis hypogaea L.). Ann. Appl. Biol. 15:26-45.

32. Storey, H. H., and Ryland, A. K. 1957. Viruses causing rosette and other diseases in groundnuts. Ann. Appl. Biol. 45:319-326.

33. Taliansky, M. E., Robinson, D. J., and Murant, A. F. 1996. Complete nucleotide sequence and organization of the RNA genome of groundnut rosette umbravirus. J. Gen. Virol. 77:2335-2345.

34. Thresh, J. M. 1983. Progress curves of plant virus diseases. Adv. Appl.
Biol. 8:1-85.

35. Tjallingii, W. F. 1985. Membrane potentials as an indication for plant cell penetration by aphid stylets. Entomol. Exp. Appl. 38:187-193.

36. Tjallingii, W. F. 1988. Electrical recording of stylet penetration activities. Pages 95-108 in: Aphids, Their Biology, Natural Enemies and Control. A. K. Minks and P. Harrewijn, eds. Elsevier, Amsterdam.

37. Watson, M. A., and Okusanya, B. A. M. 1967. Studies on the transmission of groundnut rosette virus by Aphis craccivora Koch. Ann. Appl. Biol. 60:199-208. 